\title{
Use of -Based Interactive Learning Media Visuals in Science Learning
}

\author{
Uswatun Hasanah $^{1 *}$, Putu Sudira ${ }^{2}$ (D) \\ 1,2 Prodi Pendidikan Teknologi dan Kejuruan, Universitas Negeri Yogyakarta, Indonesia
}

\section{A R T I C L E I N F O}

Article history:

Received June 12, 2021

Revised June 15, 2021

Accepted September 12, 2021

Available online November 25, 2021

Kata Kunci:

Media Visual, Interaktif, IPA

Keywords:

Visual Media, Interactive, Science

DOI:

https://dx.doi.org/10.23887/jet.v5i4 35364

\begin{abstract}
A B S T R A K
Masalah mendasar dalam penyelenggaraan pendidikan pada jenjang pendidikan adalah proses pembelajaran pada umumnya terlalu berorientasi pada penguasaan materi pelajaran, bukan pada substansi, makna, atau nilai yang dikandungnya. Penelitian ini bertujuan untuk menganalisis keberhasilan dari penggunaan media interaktif berbasis visual atau media gambar pada pembelajaran IPA. Jenis penelitian True eksperiment dengan pendekatan kuantitatif. Subjek dalam penelitian ini sebanyak 50 siswa yang terdiri dari 2 kelas terpisah, jumlah siswa perempuan 30 dan siswa laki-laki 20. Metode pengumpulan data pada penelitian ini dengan menggunakan hasil belajar siswa pre test dan post test. Instrumen yang digunakan adalah tes hasil belajar dan angket respon siswa. Teknik yang digunakan untuk menganalisis data yaitu analisis deskritif kualitatif dan kuantitatif serta statistika inferensial. Hasil penelitian diperoleh hasil skor rata-rata belajar IPA setelah penggunaan media pembelajaran interaktif berbasis visual adalah 75,93 dengan standar deviasi 16,19. Skor terendah pada siswa adalah 40 dan skor tertinggi adalah 99. Media interaktif berbasis visual efektif digunakan untuk meningkatkan hasil belajar IPA pada siswa. Implikasi penelitian yaitu media Media interaktif berbasis visual daoat digunakan oleh guru dalam mengajar sehingga dapat membantu siswa dalam belajar.
\end{abstract}

\section{A B S T R A C T}

The fundamental problem in implementing education at the education level is that the learning process is generally too oriented to mastery of subject matter, not to the substance, meaning, or value it contains. This study aims to analyze the success of using visual-based interactive media or image media in science learning. This type of research is an actual experiment with a quantitative approach. The subjects in this study were 50 students consisting of 2 separate classes, the number of female students was 30 , and the number of male students was 20 . The method of data collection in this study used student learning outcomes pre-test and post-test. The instrument used is a test of learning outcomes and student response questionnaires. The technique used to analyze the data is the descriptive qualitative and quantitative analysis and inferential statistics. The results showed that the average score of learning science after using visual-based interactive learning media was 75.93, with a standard deviation of 16.19. The lowest score for students is 40 , and the highest score is 99 . Visual-based interactive media is effectively used to improve student learning outcomes in science. The research implication is that visualbased interactive media can be used by teachers in teaching so that they can help students learn.

This is an open access article under the CC BY-SA license. Copyright @ 2021 by Author. Published by Universitas Pendidikan Ganesha.

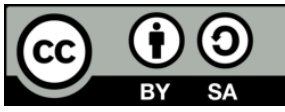

\section{INTRODUCTION}

Educational technology that is oriented towards observing constant improvement in learning practices by utilizing one of the visualization technologies that can improve students' perceptions in carrying out the learning process in the classroom (Chen \& Li, 2011; Lestari et al., 2021; Putrawangsa \& Hasanah, 2018). Interactive role in learning enhanced by current technological developments in education (Tuma, Malgor, \& Nassar 2021; Ran and Jinglu 2020). Education in the era of the industrial revolution 4.0 with technological sophistication that develops is can change various sectors, especially in the teaching and learning process of teachers and students which in supporting the success of the learning process students are required to master various subject matter delivered by the teacher, but the success of the material is marked by the ability to teachers in managing and developing creative and innovative learning media to give birth to a quality generation and able to compete globally (Mutohhari et al., 2021; Rusli et al., 2020; Sriyanti et al., 2021). Learning design is sought so that students can carry out learning activities by utilizing currently developing technology (Buchori et al., 2017; Nonthamand, 2020). One of the main factors for the lack of enthusiasm in students to participate in 
learning is that teachers are still difficult in developing a supporting media in learning and there are some teachers who find it difficult to use the technology that is currently developing (Akyol \& Garrison, 2011; Fauyan, 2019). Thus a teacher must have a strategy that can arouse enthusiasm and activate students in the classroom during the teaching and learning process so that there is interaction between the two teachers and students (Alias et al., 2012; Filgona et al., 2017; Rosciano, 2015). This certainly affects the success of learning.

The expected learning is in the form of quality learning (Seibert, 2020; Suwana et al., 2013). In this case previously a teacher only carried out a conventional teaching and learning process centered on the teacher, presenting the material using the lecture method with students listening to the material and being given assignments without any feedback (Li et al., 2021; Tsivitanidou \& Constantinos, 2016). Improving understanding, various ideas and arguments in students can increase self-confidence with interactive learning, learning that is updated following the times and supported by learning media. Learning media can help the development of student learning outcomes (Boyd, 2019; Buchori et al., 2017). Another fundamental problem in the implementation of education at the primary and secondary education levels is that the learning process is generally too oriented to mastery of subject matter, not to the substance, meaning, or value it contains (Nurlaily et al., 2019; Toma et al., 2019). This means that the learning models that have been applied so far tend to be too theoretical and not related to the environment, learning is more class-based with lecture methods and general questions and experience which is more precisely still using conventional methods in managing learning (Batdi, 2014; Sallehhuddin et al., 2018). The use of less audio-visual media and the high dominance of teachers teaching with the lecture method will make students bored so that it can cause low student learning outcomes. In addition, student learning outcomes in science learning in class VII Mts YPUI Al-Ikhwan Topoyo are currently following the applicable curriculum, namely the 2013 curriculum. Science learning usually includes reading, writing, listening, and sometimes direct observation in the field identify questions and draw conclusions based on evidence. There are several difficulties in learning science, such as students who lack concentration in listening to the teacher's explanations, students who have difficulty finding examples of the material presented, and teachers are more centered on what is conveyed by the lecture method, this is because one of them is learning does not use the lecture method. learning media is the main support in the teaching and learning process.

A teacher must be able to provide services to convey his knowledge as best as possible to students so that the knowledge of students changes and increases (Benavides-Varela et al., 2020; Fujiyanto et al., 2016). Therefore, teachers are required to be able to create varied learning and by using learning media that support the material (Mulyanto et al., 2020; Oktafiani et al., 2020). Of the many functions of media, one of the main functions of learning media is as an intermediary capable of conveying messages or information so that they can support and have a good impact on the quality of learning provided by educators, such as learning motivation for students, encouragement to learn and emotional feelings students to take part in learning so that they can involve students directly in their use (Buchori et al., 2017; Ja'ashan, 2020). Interactive multimedia is an intermediary tool that conveys messages with collaboration from various elements that can create active learning so that messages from the information conveyed can be well received. Multimedia can create active learning for students so that it can influence students' thinking power and can provide input for the media (Lauc et al., 2020; Leszczyński et al., 2018). This supports researchers to develop visual-based interactive learning media on science subjects in class VII that utilizes image material in science learning. The use of this media is necessary because there is still very little use of media in schools where researchers conduct research, especially interactive media (Khan \& Masood, 2015; Majid et al., 2012). The concept of material in science learning, especially material that is more precise about living things and their environment because this material visualizes the concept of pictorial material so that students are easier to understand the material presented by the teacher which has been made using image media by the needs of science learning material (Marnita \& Ernawati, 2017; Widjayanti et al., 2019).

The main goal of the researcher is to develop visual-based interactive media so that students are more active, interact with each other, are sensitive to the environment inside and outside the classroom. Able to digest explanations from teachers and students can be sensitive that the learning environment uses learning media. Media is designed to increase persistence in learning and provide convenience for teachers and listeners (Fauyan, 2019; Sittichailapa et al., 2015). In addition, in the delivery of science in an integrated manner, a facility and devices that support science learning are needed (Manurung \& Panggabean, 2020; Rahayu et al., 2012). Multimedia is a combination of several media to present information holistically (Khamparia \& Pandey, 2017; Komalasari \& Rahmat, 2019). The purpose of this study is to produce interactive learning using visual-based media with indicators of success from using visual-based media to see the completeness of science learning outcomes, and student responses to science learning media. The use of learning media is very influential on success in the teaching and learning process. Interactive multimedia is a collection of several media such as texts, images, audio, video, visuals, and interactive animations that are used to convey information and as a means for teachers to deliver learning materials to students. 


\section{METHOD}

This research can be classified as true experiment research with a quantitative approach. The research subjects consisted of two classes, namely the experimental class and the control class. The treatment (treatment) used visual media in the experimental class while the control class used conventional media. At the initial stage, a pre-test was used to determine the level of mastery of students' abilities in mastering science learning for class VII MTs YPUI Al-Ikhwan. The research design used in this study was a pretest-posttest control group design with one type of treatment. The population in this study were seventh-grade students of MTs YPUI Al-Ikhwan Topoyo which consisted of 3 classes, each class A, B and C. Pesantren-based schools for the learning process of male and female classes were separated, male classes were divided 2 classes because in one there are only 20 students for the male class, while for the female class there is only 1 class. And the sample is class VII A and B. Determination of this sample is done through a simple random sampling technique, that is, each individual in the population has an equal opportunity to be selected as a member of the sample. The experimental class will be given special treatment by using visual-based interactive learning media, while the control class will use conventional learning methods. After the two classes were held such learning, then a test was conducted to determine the differences in the learning outcomes of the two classes, both in terms of cognitive, affective, and psychomotor.

The grid in this research instrument : Is about cognitive tests in the form of pre-test and post-test learning outcomes related to science learning materials related to the interaction of living things and the environment, aiming to measure student learning outcomes before and after being given treatment. The form of multiple choice questions and descriptions with 18 questions and Questionnaire of student responses to science learning using visual-based interactive media by presenting questions and statements with 25 questionnaire items, each indicator explaining satisfaction in learning using visual-based interactive media. Research data analysis uses descriptive statistics that emphasize the discussion of data and research subjects by presenting data systematically, such as data analysis of science learning outcomes for students and using inferential statistical analysis. The data analyzed are test data at the beginning and end after the data is collected and processed to calculate the test results using the F-test data analysis technique, namely normality, homogeneity and hypothesis tests.

\section{RESULT AND DISCUSSION}

\section{Result}

As described in the previous background, the purpose of this study is to describe the effectiveness of using visual-based interactive learning media in science learning for class VII MTs YPUI Al-Ikhwan Topoyo with Islamic nuances. To determine the effectiveness of using visual-based interactive learning media, experimental research procedures and data analysis were carried out using descriptive statistics and inferential statistics. The concept in this study is more about the use of visual-based learning media.The first stage: Description of the Ability Test (Pretest) for the Experimental class. In calculations using SPSS version 18 on the pre-treatment data (pre-test) in the experimental class, the number of valid samples is 27 , the mean score $=$ 73.67 , the mean $=72.00$, standard deviation $=16.20$, standard deviation 16.20 , minimum value $=40$ and maximum $=96$.

Second Stage: Description of the Ability Test (Post-test) for the Experimental class After the post-test treatment in the experimental class, the number of valid samples was 27 , the mean score $=75.93$, the mean $=$ 75.00. Third Stage: Description The ability test (pre-test) of the control class in the control class obtained a valid sample of 20 , the mean score $=76.75$, the mean $=80.00$, the standard deviation is 90 , the standard deviation is 19.47, the minimum value $=22$ and maximum $=90$. Fourth Stage: Description of the ability test (post-test) in the control class, the number of valid samples is 20 , the mean score $=70.80$, the mean $=70.00$, the standard deviation is 80 , the standard deviation is 17.01 , the minimum value is $=22$ and maximum $=85$.

Fifth Stage: Description of Student Activity Observation Results in Visual-based Interactive Learning The criteria for the success of student activities in this study are said to be effective if at least $75 \%$ of students are actively involved in the learning process. Based on table 4.8, it can be said that student activities in this study have been effective. This can be seen from the percentage of students who attend teaching and learning activities during four meetings as much as $98.33 \%$, the percentage of students who pay attention to the material as much as $95.83 \%$, the percentage of students who can answer questions asked by the teacher about the material being studied is $75 \%$, students who ask questions about subject matter that has not been understood during the learning process as much as $76.67 \%$, students who can work together with their group friends as much as $93.33 \%$.

Students who can make a material concept and look for alternative solutions to problems with their group friends are $80.83 \%$, students who record ideas and opinions during the discussion are $98.33 \%$, students who can explain concepts that have been made with their sentences and thoughts are as many as $70 \%$, students 
were able to develop an understanding of the concept into a concept map as much as $72.5 \%$, from several activities observed during four meetings, the average percentage of positive student activities was $84.54 \%$ of students who were active in learning mathematics. From the table, it can also be seen that from the four meetings observed, only $4.17 \%$ of students engaged in other activities during the learning process, and $2.5 \%$ of students who left the classroom were in and out.

The pre-test and post-test data on learning outcomes for both the experimental class and control class have a sig value $>0.05$ obtained by the experimental class and control class from posttest to pretest, it can be concluded that the data group normally distributed. The results of the homogeneity test of the research variables are known that the pre-test calculated $\mathrm{F}$ value is 2.596 with a significant value of 0.093 while the post-test $\mathrm{F}$ count is 0.724 with a significant value of 0.656 . From the results of the calculation of the significant price of the pre-test or post-test data greater than 0.05 ( $\mathrm{sig}>0.05$ ), it can be concluded that the data in this study has a homogeneous variance. The average pre-test value of the experimental class was 73.66 and the average post-test score was 75.93, increasing to 2.27. Also found $\mathrm{Ac}_{\text {count }}<\mathrm{T}_{\text {able }}$ at a significance level of $5 \%(0.131<2.055)$ and has a p-value of $<0.05$, which means that it can be concluded that there is a significant increase in student learning outcomes in the experimental group.

The average pre-test value for the experimental class was 76.75 and the post-test average was 70.80 so that it experienced an increase of 5.95. It was also found that $\mathrm{Ac}_{\mathrm{count}}<\mathrm{T}_{\text {table }}$ at a significance level of $5 \%(0.702<$ 2.093 ) and had a p-value of $<0.05$, which means that it can be concluded that there was a significant increase in student learning outcomes in the control group. Based on the calculation results of the independent sample t-test, it is known that the average increase in the experimental group is 75.93, while the increase in the control class is 70.80 so it is known that the increase in the experimental class's learning score is 5.13 greater than the control class. It is also known that the value of $\mathrm{Ac}_{\text {count }}$ is 0.807 with a significance of 0.000 . The value of the $\mathrm{T}_{\mathrm{able}}$ is 2.014. So it can be concluded that $\mathrm{Ac}_{\text {count }}<\mathrm{T}_{\text {able }}(0.807<2.014)$ and the significance value is more than $0.05(\mathrm{p}=$ $0.000<0.05)$, so it can be stated that there is a significant difference in increasing the score of learning outcomes significantly in the experimental group and the control group.

\section{Discussion}

The results of the data analysis of student learning outcomes after learning science using learning media showed that the class VII A students who did not reach the Minimum Completeness Criteria (KKM) were 4 students or $14.8 \%$ this was because these students carried out more other activities during the learning process and some students pay less attention to the application of the media. Meanwhile, 23 students, or $75.93 \%$ of students have achieved the Minimum Completeness Criteria (KKM) with the numbers obtained according to the KKM standard. Interactive media can make students active and not just passive listeners. Integrated science learning is one model of curriculum implementation that is recommended to be applied at the basic education level, namely elementary and junior high schools (Ibrahim \& Alqahtani, 2018; Rahayuningsih, 2020; Reskiani \& Supriadi, 2020). The implementation of integrated science learning requires adequate teacher professionalism (Lai et al., 2019; Supriyadi et al., 2020; Suryawati \& Osman, 2018). Teachers must have enough knowledge in conveying science knowledge as a whole (Rubini et al., 2018).

In the school environment, not all teachers apply learning using media as a supporter in the teaching and learning process, but if studied more deeply $91 \%$ of teachers agree with the development of technology media in supporting learning. Because they see student development after applying visual-based media, student learning outcomes increase (Hillmayr et al., 2020; Saisabila, 2018). To facilitate the teaching and learning process for students, school teachers are increasing the number of interactive learning environments (ILE) in the classrooms. With this students will be more active there is feedback from the teacher to students (Ceresia, 2017; Irawan \& Suryo, 2017). This interactive multimedia was developed to be used as a learning medium, especially material in science learning related to living things and their environment in daily life by requiring visualization media so that the material is more easily conveyed by the teacher to students (Fauyan, 2019; Marnita \& Ernawati, 2017; Nashirotun, 2020). Based on the above analysis, which has been linked between previous studies, it has been proven that there is a significant difference between the use of visual-based interactive media and the comparison using the lecture method without learning media in improving student learning outcomes and student responses to science learning (Science of Natural Sciences) increase student interest and motivation as found by previous researchers (Kartika et al., 2019; Manurung \& Panggabean, 2020; Primamukti \& Farozin, 2018). The thing that causes learning using visual-based interactive learning media has a higher average and increase in the distribution of values compared to learning using the lecture method because learning using media brings more active students in the classroom in the learning process even though the presentation of visual media is less than optimal, but participants students can be more active in presenting the material by using visual media. 


\section{CONCLUSION}

The results of learning science for Class VII A MTs YPUI Al-Ikhwan Topoyo students using visualbased interactive media can be said to be effective with several supporting factors in designing and designing visual media that are more prototaive and fun for students, where students who were previously bored with the method Lectures delivered by the teacher when explaining the material, students can divert their attention from various directions so that what is conveyed by the teacher is not absorbed properly. Therefore, to overcome this, researchers seek to design learning materials in the form of prototaive images so that students can play an active role in solving some of the problems they find during the provision of teaching materials.

\section{REFERENCES}

Astra, G. N. W., Suarjana, I. M., \& Suwatra, I. I. W. 2013. Pengaruh model pembelajaran problem solving berbantuan media video pembelajaran matematika terhadap kemampuan pemecahan masalah siswa IV gugus IV kecamatan Sukasada. Jurnal Mimbar PGSD Universitas Pendidikan Ganesha, 1(1). https://ejournal.undiksha.ac.id/index.php/JJPGSD/article/view/1399/1260.

Akyol, Z., \& Garrison, D. R. (2011). Understanding cognitive presence in an online and blended community of inquiry: Assessing outcomes and processes for deep approaches to learning. British Journal of Educational Technology, 42(2), 233-250. https://doi.org/10.1111/j.1467-8535.2009.01029.x.

Alias, A. A., Manan, N. A. A., Yusof, J., \& Pandian, A. (2012). The use of Facebook as Language Learning Strategy (LLS) Training Tool on College Students' LLS use and Academic Writing Performance. Procedia - Social and Behavioral Sciences, 67. https://doi.org/10.1016/j.sbspro.2012.11.305.

Batdi, V. (2014). The effects of a problem-based learning approach on students' attitude levels: A meta-analysis. Educational Research and Reviews, 9(9). https://doi.org/10.5897/ERR2014.1771.

Benavides-Varela, S., Callegher, C. Z., Fagiolini, B., Leo, I., Altoè, G., \& Lucangeli, D. (2020). Effectiveness of digital-based interventions for children with mathematical learning difficulties: A meta-analysis. Computers \& Education, 157. https://doi.org/10.1016/j.compedu.2020.103953.

Boyd, L. (2019). Using Technology-Enabled Learning Networks to Drive Module Improvements in the UK OpenUniversity. Journal of Interactive Media in Education, 2019(1), 1-7. https://doi.org/10.5334/jime.529.

Buchori, Rahmawati, S., \& Wardani, S. (2017). The Development of A Learning Media for Visualizing the Pancasila Values Based on Information and Communication Technology. Jurnal Cakrawala Pendidikan, 36(3), 502-521. https://doi.org/10.21831/cp.v36i3.12748.

Ceresia, F. (2017). Sunny Island. An Interactive Learning Environment to Promote Systems Thinking Education for Primary School Students. Procedia - Social and Behavioral Sciences, 237(June 2016), 980-985. https://doi.org/10.1016/j.sbspro.2017.02.139.

Chen, E., \& Li, Z. (2011). On the application of multimedia technology in foreign language teaching and learning in China's colleges: Challenges, problems and implications. 2011 International Conference on Multimedia Technology, ICMT 2011, 595-597. https://doi.org/10.1109/ICMT.2011.6001903.

Fauyan, M. (2019). Developing Interactive Multimedia Through Ispring on Indonesian Language Learning with The Insights of Islamic Values in Madrasah Ibtidaiyah. Al Ibtida: Jurnal Pendidikan Guru MI, 6(2), 177. https://doi.org/10.24235/al.ibtida.snj.v6i2.4173.

Filgona, J., Filgona, J., \& Linus, K. S. (2017). Mastery Learning Strategy and Learning Retention: Effects on Senior Secondary School Students' Achievement in Physical Geography in Ganye Educational Zone, Nigeria. Asian Research Journal of Arts \& Social Sciences, 2(3). https://doi.org/10.20944/preprints201702.0018.v1.

Fujiyanto, A., Jayadinata, A. K., \& Kurnia, D. (2016). Penggunaan Media Audio Visual Untuk Meningkatkan Hasil Belajar Siswa Pada Materi Hubungan Antarmakhluk Hidup. Jurnal Pena Ilmiah, 1(1), 841-850. https://doi.org/10.23819/pi.v1i1.3576.

Hillmayr, D., Ziernwald, L., Reinhold, F., Hofer, S. I., \& Reiss, K. M. (2020). The potential of digital tools to enhance mathematics and science learning in secondary schools: A context-specific meta-analysis. $\begin{array}{lllll}\text { Computers and } & \text { Education, 2018), } & \end{array}$ https://doi.org/10.1016/j.compedu.2020.103897.

Ibrahim, H., \& Alqahtani, A. S. H. (2018). The impact of adopting Web 2.0-based E-Book on student learning skills. Eurasia Journal of Mathematics, Science and Technology Education, 14(6), 2509-2522. https://doi.org/10.29333/ejmste/90085.

Irawan, E., \& Suryo, T. (2017). Implikasi Multimedia Interaktif Berbasis Flash Terhadap Motivasi dan Prestasi Belajar Matematika. Beta Jurnal Tadris Matematika, 10(1), 33. https://doi.org/10.20414/betajtm.v10i1.17. 
Ja'ashan, M. (2020). The Challenges and Prospects of Using E-learning among EFL Students in Bisha University. Arab World English Journal, 11(1), 124-137. https://doi.org/10.24093/awej/vol11no1.11.

Kartika, Y., Wahyuni, R., Sinaga, B., \& Rajagukguk, J. (2019). Improving Math Creative Thinking Ability by using Math Adventure Educational Game as an Interactive Media. Journal of Physics: Conference Series, 1179(1), 1-6. https://doi.org/10.1088/1742-6596/1179/1/012078.

Khamparia, A., \& Pandey, B. (2017). Impact of interactive multimedia in E-learning technologies: Role of multimedia in E-learning. Enhancing Academic Research With Knowledge Management Principles, April, 199-227. https://doi.org/10.4018/978-1-5225-2489-2.ch007.

Khan, F. M. A., \& Masood, M. (2015). The Effectiveness of an Interactive Multimedia Courseware with Cooperative Mastery Approach in Enhancing Higher Order Thinking Skills in Learning Cellular Respiration. Procedia - Social and Behavioral Sciences, 176, 977-984. https://doi.org/10.1016/j.sbspro.2015.01.567.

Komalasari, K., \& Rahmat, R. (2019). Living Values Based Interactive Multimedia in Civic Education Learning. International Journal of Instruction, 12(1), 113-126. https://doi.org/10.29333/iji.2019.1218a.

Lai, A. F., Chen, C. H., \& Lee, G. Y. (2019). An augmented reality-based learning approach to enhancing students' science reading performances from the perspective of the cognitive load theory. British Journal of Educational Technology, 50(1), 232-247. https://doi.org/10.1111/bjet.12716.

Lauc, T., Jagodić, G. K., \& Bistrović, J. (2020). Effects of Multimedia Instructional Message on Motivation and Academic Performance of Elementary School Students in Croatia. International Journal of Instruction, 13(4), 491-508. https://doi.org/10.29333/iji.2020.13431a.

Lestari, K. B., Dwi Lestari, I. F., \& Santoso, I. (2021). The Impact of Health Education Using Online Learning on Adolescent Knowledge of Anaemia. KnE Social Sciences, 2021, 209-220. https://doi.org/10.18502/kss.v5i3.8541.

Leszczyński, P., Charuta, A., Łaziuk, B., Gałązkowski, R., Wejnarski, A., Roszak, M., \& Kołodziejczak, B. (2018). Multimedia and Interactivity in Distance Learning of Resuscitation Guidelines: A Randomised Controlled Trial. Interactive Learning Environments, 26(2), 151-162. https://doi.org/10.1080/10494820.2017.1337035.

Li, F.-Y., Hwang, G.-J., Chen, P.-Y., \& Lin, Y.-J. (2021). Effects of a concept mapping-based two-tier test strategy on students' digital game-based learning performances and behavioral patterns. Computers \& Education, 24. https://doi.org/10.1016/j.compedu.2021.104293.

Majid, M. S. Z. B. A., Ali, M. M. B. A., Rahim, A. A. B. A., \& Khamis, N. Y. B. (2012). The Development of Technical English Multimedia Interactive Module to Enhance Student Centered Learning (SCL). Procedia - Social and Behavioral Sciences, 67, 345-348. https://doi.org/10.1016/j.sbspro.2012.11.337.

Manurung, \& Panggabean. (2020). Improving Students' Thinking Ability In Physics Using Interactive Multimedia Based Problem Solving. Cakrawala Pendidikan, 39(2), 460-470. https://doi.org/10.21831/cp.v39i2.28205.

Marnita, \& Ernawati. (2017). The Use of Interactive Multimedia (Macromedia Flash) to Increase Creative Thinking Ability of Students in Basic Physics Subject. Jurnal Pendidikan Fisika Indonesia, 13(2), 7178. https://doi.org/10.15294/jpfi.v13i2.10152.

Mulyanto, B. S., Sadono, T., Koeswanti, H. D., Dasar, S., Wonodoyo, N., Tengah, J., Kristen, U., Wacana, S., \& Tengah, J. (2020). Evaluation of Critical Thinking Ability with Discovery Lerning Using Blended Learning Approach in Primary School. Journal of Educational Research and Evaluation, 9(2), 78-84. https://doi.org/10.15294/jere.v9i2.46135.

Mutohhari, F., Sofyan, H., \& Nurtanto, M. (2021). Technological Competencies: A Study on the Acceptance of Digital Technology on Vocational Teachers in Indonesia. Proceedings of the 1st International Conference on Law, Social Science, Economics, and Education, ICLSSEE 2021, 1-11. https://doi.org/10.4108/eai.6-3-2021.2305971.

Nashirotun, B. (2020). Peningkatan Aktivitas dan Hasil Belajar Siswa dengan Metode Jigsaw dan Media Tubuh Manusia pada Pembelajaran IPA di MTs. Negeri 4 Klaten Jawa Tengah. Jurnal Paedagogy, 7(4), 402. https://doi.org/10.33394/jp.v7i4.2945.

Nonthamand, N. (2020). Guideline to develop an instructional design model using video conference in open learning. International Journal of Emerging Technologies in Learning, 15(3), 140-155. https://doi.org/10.3991/ijet.v15i03.10842.

Nurlaily, V. A., Soegiyanto, H., \& Usodo, B. (2019). Elementary school teacher's obstacles in the implementation of problem-based learning model in mathematics learning. Journal on Mathematics Education, 10(2), 229-238. https://doi.org/10.22342/jme.10.2.5386.229-238.

Oktafiani, D., Nulhakim, L., \& Alamsyah, T. P. (2020). Pengembangan media pembelajaran IPA berbasis multimedia interaktif menggunakan Adobe Flash pada Kelas IV. Mimbar PGSD Undiksha, 8(3), 527540. https://doi.org/2614-4727. 
Primamukti, A. D., \& Farozin, M. (2018). Utilization of interactive multimedia to improve learning interest and learning achievement of child. Jurnal Prima Edukasia, 6(2), 111-117. https://doi.org/10.21831/jpe.v6i2.19183.

Putrawangsa, S., \& Hasanah, U. (2018). Integrasi Teknologi Digital Dalam Pembelajaran Di Era Industri 4.0. Jurnal Tatsqif, 16(1), 42-54. https://doi.org/10.20414/jtq.v16i1.203.

Rahayu, P., Mulyani, S., \& Miswadi, S. S. (2012). Pengembangan pembelajaran IPA terpadu dengan menggunakan model pembelajaran problem base melalui lesson study. Jurnal Pendidikan IPA Indonesia, 1(1), 63-70. https://doi.org/10.15294/jpii.v1i1.2015.

Rahayuningsih, S. (2020). Animation media of animal husbandry thematic science learning to stimulate scientific attitude in early childhood. International Journal of Scientific and Technology Research. https://doi.org/10.23887/jet.v3i1.17959 Article Metrics.

Ran, W., \& Jinglu, L. (2020). The Design and Development of Digital Books for E-learning. 2020 4th International Conference on Artificial Intelligence and Virtual Reality, 51-55. https://doi.org/10.1145/3439133.3439140.

Reskiani, \& Supriadi. (2020). Implementation of Advance Organizer learning Model Based on Numbered Heads Together (NHT) to Improve Learning Outcomes of Studeny in 11th Grade Science on Buffer at SMAN 2 Balaesang. Jurnal Akademika Kimia, 9(2). https://doi.org/10.22487/j24775185.2020.v9.i3.pp1.

Rosciano, A. (2015). The effectiveness of mind mapping as an active learning strategy among associate degree nursing students. Teaching and Learning in Nursing, 10(2). https://doi.org/10.1016/j.teln.2015.01.003.

Rubini, B., Permanasari, A., \& Yuningsih, W. (2018). Learning Multimedia Based on Science Literacy on the Lightning Theme. Jurnal Penelitian Dan Pembelajaran IPA, 4(2), 89-104. https://doi.org/10.30870/jppi.v4i2.3926.

Rusli, R., Rahman, A., \& Abdullah, H. (2020). Student perception data on online learning using heutagogy approach in the Faculty of Mathematics and Natural Sciences of Universitas Negeri Makassar, Indonesia. Data in Brief, 29, 105152. https://doi.org/10.1016/j.dib.2020.105152.

Saisabila, A. (2018). Pengaruh Model Student Facilitator and Explaining Berbantuan Media Visual Non Proyeksi Terhadap Kompetensi Pengetahuan Ipa. Indonesian Journal Of Educational Research and Review, 1(1), 1-10. https://doi.org/10.23887/ijerr.v1i1.14616.

Sallehhuddin, A., Shamsudin, A., Abu Said, A. M., Jais, M., Ariff Mustafa, M., Shukor Masuod, M., Hasmanto, N., \& Ismail, H. (2018). Board Governance Attributes and Organizational Characteristics of Mosque Co-Operatives in Malaysia. International Journal of Engineering \& Technology, 7(2.29), 321. https://doi.org/10.14419/ijet.v7i2.29.13646.

Seibert, S. A. (2020). Problem-based learning: A strategy to foster generation Z's critical thinking and perseverance. Teaching and Learning in Nursing, 000, 2-5. https://doi.org/10.1016/j.teln.2020.09.002.

Sittichailapa, T., Rattanachai, R., \& Polvieng, P. (2015). The Development of Model Learning Media of Sorting Algorithm. Procedia - Social and Behavioral Sciences, 197(February), 1064-1068. https://doi.org/10.1016/j.sbspro.2015.07.333.

Sriyanti, I., Almafie, M. R., Marlina, L., \& Jauhari, J. (2021). The effect of Using Flipbook-Based E-modules on Student Learning Outcomes. Kasuari: Physics Education Journal (KPEJ), 3(2), 69-75. https://doi.org/10.37891/kpej.v3i2.156.

Supriyadi, T., Julia, J., Aeni, A. N., \& Sumarna, E. (2020). Action research in hadith literacy: A reflection of hadith learning in the digital age. International Journal of Learning, Teaching and Educational Research, 19(5), 99-124. https://doi.org/10.26803/ijlter.19.5.6.

Suryawati, E., \& Osman, K. (2018). Contextual learning: Innovative approach towards the development of students' scientific attitude and natural science performance. Eurasia Journal of Mathematics, Science and Technology Education, 14(1), 61-76. https://doi.org/10.12973/ejmste/79329.

Suwana, I. G. G., Artini, L. P., \& Piscayanti, K. S. (2013). The Use Of R.A.P Paraphrasing Strategy To Improve Students' Reading Comprehension At Class X.A3 In Smkn 2 Singaraja In Academic Year 2013/2014. Jurnal Pendidikan Bahasa Inggris Undiksha, 1(1). https://doi.org/10.23887/jpbi.v1i1.3859.

Toma, R. B., Greca, I. M., \& Orozco Gómez, M. L. (2019). Attitudes towards science and views of nature of science among elementary school sToma, R. B., Greca, I. M., \& Orozco Gómez, M. L. (2019). Attitudes towards science and views of nature of science among elementary school students in terms of gender, cultur. Research in Science and Technological Education, 37(4), 492-515. https://doi.org/10.1080/02635143.2018.1561433.

Tsivitanidou, O. E., \& Constantinos. (2016). A study of students' heuristics and strategy patterns in web-based reciprocal peer assessment for science learning. The Internet and Higher Education, 29. https://doi.org/10.1016/j.iheduc.2015.11.002.

Tuma, F., Malgor, R. D., \& Nassar, A. K. (2021). Actions to enhance interactive learning in surgery. Annals of Medicine and Surgery, 64(March), 102256. https://doi.org/10.1016/j.amsu.2021.102256. 
Widjayanti, W. R., Masfingatin, T., \& Setyansah, R. K. (2019). Media Pembelajaran Interaktif Berbasis Animasi Pada Materi Statistika Untuk Siswa Kelas 7 Smp. Jurnal Pendidikan Matematika, 13(1), 101-112. https://doi.org/10.22342/jpm.13.1.6294.101-112. 